\title{
An approach to the biological, historical and psychological repercussions of gender verification in top level competitions
}

\author{
MARÍA JOSÉ MARTÍNEZ-PATIÑO ${ }^{1}$, COVADONGA MATEOS-PADORNO², AURORA MARTÍNEZ- \\ VIDAL ${ }^{3}$, ANA MARÍA SÁNCHEZ MOSQUERA ${ }^{1}$, JOSÉ LUIS GARCÍA SOIDÁN", MARÍA DEL PINO DÍAZ \\ PEREIRA ${ }^{3}$, CARLOS FRANCISCO TOURIÑO GONZÁLEZ1 \\ ${ }^{1}$ Faculty of Science Education and Sport, University of Vigo, Pontevedra, Spain. \\ ${ }^{2}$ Department of Physical Education, University of Las Palmas, Campus Universitario de Tafira, Spain \\ ${ }^{3}$ Special Didactics Department. Faculty of Science Education. University of Vigo. Orense, Spain
}

\begin{abstract}
Martínez-Patiño MJ, Mateos-Padorno C, Martínez-Vidal A, Sánchez AM, García JL, Díaz MP, Touriño CF. An approach to the biological, historical and psychological repercussions of gender verification in top level competitions. J. Hum. Sport Exerc. Vol. 5, No. 3, pp. 307-321, 2010. Different kinds of disorders of sex development (DSD) have been observed in athletes from different countries along the history of sport. The detection of an abnormal chromosomal pattern or gonadal dysgenesis has been always associated to the gender verification tests which international sports institutions have performed from 1960s and abandoned as systematic practice in 2000 . Such methods have been heavily criticized by specialists of different fields such as genetics, endocrinologists and psychologists. The use of a femininity control at the present days to detect possible males who fraudulently pretend to compete in female only events is inconsistent. The possible decision of the International Olympic Committee to establish special centers to manage future DSD cases is also discussed. A major concern on the confidentiality between doctors and patients and the establishment of care protocols for the psychological support of athletes in such delicate situations is needed. This ties altogether with the psychological and social repercussions of the gender verification on the lives of athletes with DSD. When cases of sex ambiguities are detected, issues such as the respect of privacy, the need of specific protocols to follow with flexible and diversified tests considering the particularity of each case as well as the psychological support of the athletes and their family have to be taken into account. Although health tests are needed for both men and women, DSD athletes should not be discriminated for their genetic pattern and they should be allowed to compete as it occurs with other athletes with genetic affections which do not involve the sex and that give them a phenotypical advantage over other athletes. Key words: GENDER TEST, DISORDERS SEX DEVELOPMENT (DSD), GENDER VERIFICATION, SPORT, FEMALE
\end{abstract}

Corresponding author. Faculty of Science Education and Sport, University of Vigo. Campus A Xunqueira s/n. 36005 Pontevedra, Spain.

E-mail:mjpatino@uvigo.es

Submitted for publication July 2010.

Accepted for publication September 2010.

JOURNAL OF HUMAN SPORT \& EXERCISE ISSN 1988-5202

(c) Faculty of Education. University of Alicante

doi:10.4100/jhse.2010.53.01 


\section{INTRODUCTION}

Along the history of sport, a large number of cases of gender disorders has been reported. Before any athlete is allowed to compete in women's events at the Olympics, and many other international meetings, she first has to prove she is a woman. Passing this screen test - known as "gender verification" or "sex texting" - has nothing to do with the way a woman looks, her birth records, or her sense of self. Testing began in the mid 1960s in response to rumors about men masquerading as women and of women "who weren't really women" in competition. The purpose, officially stated by the International Olympic Commmittee (IOC) is to "guarantee physical equality" and prevent "unfair, male-like competition". There is no telling how many hundreds, probably thousands, of girls have either "self-disqualified" prior to competition; or been disqualified at lower levels of sport (including via "pre-testing" at regional training centers), where screening based on IOC example has been done on a widespread basis with no guarantees for quality control. Test data is supposed to be kept confidential, according to standard medical practice.

The whole procedure will start with a gender testing method which varied from undressing in front of a panel of gynaecologists, to the external genitalia examination, chromosome analysis and the application of the x-chromatin test, use of modern PCR based genetic tests. There was a strong pressure to provide a rapid gender determination with limited information, leading to discriminating episodes. Athletes who did not consent to subjugate to a gender test (such as the track and field athletes Tamara and Irina Press) were excluded from competitions being automatically considered as men (Anonymous, 1967; Carlson, 2005). Others, such as the sprinter Ewa Klobukowska and the hurdler Maria Patiño, who did not suspect irregularities in their chromosome arrangement were also penalized by the gender verification system and had their sport careers and personal lives irremediably destroyed (Carlson, 2005; Martínez-Patiño, 2005). Maria Patiño, one of the authors of this review, struggle to appeal her disqualification from sport and with the help of sports and medicine specialists was the first person to be readmitted as a woman for sport. Her efforts represented the first step towards the abolition of the gender verification testing at international competitions, commencing from the Sidney Olympic Games in 2000 (Genel, 2002). The recent events concerning the gender verification of the 800 meters female world champion Caster Semenya and the determination of her disorder of sex development highlighted the problem and deserve a consideration. Unfortunately, the IOC had inadvertently sold the sports community a false "bill of goods": its assessment of both purpose and potential for sex chromosome screening in sports was based on a naïve science, and proves to have been severely flawed. Concerned medical specialists have protested since the beginning that such screening is inaccurate, discriminatory and the cause of sometimes severe trauma in the lives of women athletes.

The aim of the present review attempts to make a point about the disorders of sex development (DSD) and the gender verification system in top-level sport, taking into account different aspects, such as the clinical profile of DSD and the psychological and social implications of these abnormalities for women in sport. The issue goes beyond sport and medicine to the very essence of our scientific paradigm, and to our sociocultural constructs of masculinity and femininity. The implications of the debate cut right to the heart of our identity, and demand a re-examination of our notions of femininity, equality and fair play. 


\section{CLINICAL PROFILE OF DSD IN SPORT}

There are different factors which combined make up the sex of an individual and gonad differentiation and which involve a complex interaction of developmental pathways (Berkovitz \& Seeherunvong, 1998). Although in many cases no definitive causes for the disorder can be found, it seems to be due to chromosomal and monogenic disorders which inhibit or change primarily genetic or endocrine pathways of normal sex development (Thyen et al., 2007).

The genetic material for male differentiation is located in the Sry (sex determination region of the $\mathrm{Y}$ ) gene at the distal region of the short harm of the $Y$ chromosome (Fechner, 1996), which at the sixth week of development leads to the gonad induction according to the XY chromosomal material (Grumbach \& Conte, 1998). Sry gene is expressed in a small group of somatic cells of the developing gonads, and it is responsible for the expression of a male-specific cell membrane component (the H-Y antigen; Hipkin, 1993) and induces them to become Sertoli cells, which are responsible for sexual development of male pathway. The timing of when various genes and nuclear transcription modifiers are expressed can be critical in gonadal development and in ductal development and regression. Sex differentiation begins at about six weeks of embryonic life. After that, during the seventh week, primary sex cord and seminiferous evetubules develop in the testis (Francavilla et al., 1990; Rabinovici \& Jaffe, 1990), while the primary follicles develop in the ovary during the tenth week (Hughes, 2002). During the sixth week, the mesonephric duct (wolffian duct) generates the male genital vas deferens, seminal vesicles and epidydimis, and the müllerian duct generates the female genital fallopian tubes, uterus and proximal vagina (Rey et al., 2002).

Sertoli cells present in the male gonads produce a müllerian inhibiting substance (MIS) which determines the regression of the müllerian duct. The contemporary secretion of the hormone testosterone by Leyding cells and the following transformation into dihydrotestosterone (DHT) by the enzyme 5-a-steroid- reductase stimulates the development of the wolffian ducts, so that external genitalia are phenotypically male (Hipkin, 1993; Pajkrt \& Chitty, 2004). DHT is the most potent androgen in the majority of tissues, but its action requires the presence of an intracellular androgen receptor (Hipkin, 1993). When the müllerian inhibiting substances are absent the müllerian duct develops and the external genitalia are phenotypically female (Hipkin, 1993; Bomalaski, 2005).

Disorders of sex development (DSD) is a generic term encompassing any problem noted where genitalia are atypical in relation to chromosome and gonads (Lee et al., 2006) and nowadays it is used to substitute the anachronistic nomenclature "intersex", "hermaphrodite" and "pseudohermaphrodite". Although the use of this new terminology has been questioned by some genetists and endocrinologists, we have decided to use it in this review because we consider that it is a more sensitive term to define this kind of conditions. Different kinds of DSD have been classified: gonadal dysgenesis, undervirilization of $46, X Y$ individuals and prenatal or postnatal virilisation of 46,XX individuals (also known as XY DSD and XX DSD), true hermaphrodites, XXY karyotype of Klinefelter's syndrome (Hipkin, 1993; Richter-Appelt, 2007; Hughes, 2008; Warne \& Raza, 2008).

Gonadal dysgenesis refers to a defect in gonad formation that is characterized by a progressive loss of primordial germ cells in the embryo with consequent formation of hypoplastic and disfunctioning gonads mainly composed of fibrous tissue, named streak gonads. It may be due to Turner syndrome and its variants (i.e. mosaicism), to XX gonadal dysgenesis (pure gonadal dysgenesis 46XX), Swyer syndrome (pure gonadal dysgenesis 46XY), Perrault syndrome (XX gonad dysgenesis with sensorineural hearing loss), mixed gonadal dysgenesis and endocrine disruptors. 
Turner Syndrome is a chromosome abnormality in which monosomy $\mathrm{X}$ is present, consisting in the absence of all or part of one sex (Ford et al., 1959; Fraccaro et al. 1959; Sybert \& McCauley, 2004), with consequent lack of chromosomal information which causes bilateral streak gonads, short stature, webbed neck, facial dystrophism and sexual infantilism. When the sex chromosome is missing in some cells and not in others of the same individual the case is referred as Turner mosaicism (Lisker et al., 1978; Zuffardi et al., 1987) or when there are sex chromosomal different patterns in cells of the same individual we can also talk of mosaicism and in this case the subject has normal stature. A famous case of mosaicism with abnormal genitalia in female high level sport was given by the sprinter Ewa Klobukowska in 1967. The Polish sprinter was submitted to a nude parade in front of a board of gynaecologists, external genitalia examination and a chromosome analysis. Although she passed the phenotype tests, the chromosome analysis revealed a $\mathrm{XX} / \mathrm{XXY}$ mosaicism, so that she was considered as a man, banned from competitions, and all her medals and records were retired (Langlais, 1988; Carlson, 2005). Another case of mosaicism in the chromosomal pattern was the 1932 track legend Stella Walsh, whose gonadal dysgenesis was revealed by an autopsy after her death due to a shot in a cross fire of a store robbery in 1980 (Dickinson, 2002; Carlson, 2005) when she had already retired from competitions for a long time.

Pure gonadal dysgenesis 46XX is strictly correlated to Turner's syndrome and individuals with this kind of disorders are characterized by normal female external genitalia, bilateral streak gonads, amenorrhea and sexual infantilism. Since the streak gonads are not able to produce estrogens or androgens, the secondary sex characteristics do not develop and there is not breast development, widening of the pelvis and menstrual period (amenorrhea). Perrault associated the XX gonad dysgenesis with sensorineural hearing loss (Perrault et al., 1951). Subjects with pure gonadal dysplasia and a 46XY karyotype (Swyer syndrome) will display variable degrees of undermasculinization dependent upon the amount of testicular dysplasia, being possible that in some cases the müllerian ductal structures are present due to a deficient secretion of müllerian inhibiting substances. Both XX and XY gonad dysgenesis are due to mutation or deletion of part of the sequence of the Sry gene (Dickinson et al., 2002). Surgery is possible to redirect external genital to female or male "normal" structures (Bomalaski, 2005).

Cases of surgery to adjust the sex of some athletes to their chromosomal arrangement have been observed in the sport history, such as the case of the Czechoslovak runner and jumper Zdenka Koubkova and of the English shotputter and javelin thrower Mary Edith Louise Weston. Both individuals had sex change surgery and turned into men, legally changing their names to Zdenek Koubek and Mark Weston, respectively ("Change of sex", 24 Agust, 1936, Time). The 1946 European Cup medallist, Lea Caurla changed her sex after the compulsory retirement from competitions. Erika Schinegger, an Austrian ski champion, retired in 1967 after the detection of irregularities during the medical examination in the World Cup competition. After a surgery she changed of sex, competed as a man in skiing and cycling and was able to procreate. Another French athlete, Clare Bressolles underwent sex change surgery, married and fathered children (Ferguson-Smith \& Ferris, 1991; Carlson, 2005). On the contrary, the Polish athlete Ewa Klobukowska underwent surgery to extract internal testis and followed a hormone therapy to keep on going with her difficult life as a woman (Facius, 2004).

Mixed gonadal dysgenesis is a partial gonadal dysgenesis variant of the $Y$ chromosome mosaicism (Kim et al., 2002) and the subjects have 45XO/46XY karotype being characterized by unilateral testis, a contralateral streak gonad, persistent müllerian ductal structures ipsilateral with the streak gonad, and varying levels of external genitalia undervirilization (Diamond, 2002). Two-thirds of patients are reared as females while subjects with highly masculinisation are reared as male with testis preservation; careful periodic screening of the testis must be undertaken due to the risk of malignancy (Bomalaski, 2005). True 
hermaphroditism is very similar to mixed gonadal dysgenesis, although very rare, and consists in both ovarian and testicular tissues present in the same individual. The karyotype could be 47XXY, 46XX/46XY, or 46XX/47XXY.

Endocrine disruptors are exogenous substances that act like hormones in the endocrine system and disrupt the physiologic function of endogenous hormones. They are sometimes also referred to as hormonally active agents (Krimsky, 2001) or endocrine disrupting chemicals/compounds (EDC). Low dose exposure to chemicals that interact with hormone receptors could interfere with the sex development and other hormonally mediated processes in embryo.

At endocrine level, hormonal factors may play an important role in the genital phenotype. Female genital development is passive but an androgen stimulation of external (from the mother) or endogenous from an adrenal source (congenital adrenal hyperplasia) origin may cause virilisation of female genitalia (Sultan et al., 2002). A female pseudohermaphrodite or XX DSD is a genetic female with ovaries but virilized external genitalia (de la Chapele, 1981). When müllerian inhibiting substances are not produced by Sertoli cells, müllerian duct remains although the production of testosterone is normal. When a failure of the production of testosterone or of its metabolic derivates or of the androgen receptor exists (due to 21-steroidhydroxylase and 5-a-steroid-reductase deficiency), it is possible to observe an undervirilization and the generation of a male pseudohermaphrodite who has a 46XY karyotype (XY DSD) but deficient masculinisation of the external genitalia (Bomalaski, 2005). The case of Maria Patiño, who presented a $Y$ chromosome and whose labia hid testes within, is another example of the development of an individual with female phenotype and female rear at birth that was treated as a male who unfairly wanted to compete as a woman. She was born with a condition called androgen insensitivity and although the presence of the $Y$ chromosome, of rudimental testis and the secretion at puberty of testosterone, her body was unable to detect it because of a receptor dysfunction due to a mutation of a gene on the $Y$ chromosome. Without the stimulation provided by the masculine hormone, her body developed a female phenotype but did not have any competitive advantage (Blackless et al., 2000; Fausto-Sterling, 2000; Dickinson et al., 2002; Peel, 1994; Martínez-Patiño, 2005). The restatement of Maria Patiño as a woman for sport was an important step in the consideration of sex not as a well defined status but as a continuum from two extremes, the male and female sexes, with a wide variety in the middle (Fausto-Sterling, 2000).

\section{GENDER VERIFICATION TESTING IN HIGH LEVEL SPORTS}

Gender verification was introduced by the IOC to avoid the fraudulent participation of men in female only competitions, but it caused the exclusion from competitions of athletes with genetic disorders that did not have any advantage over female athletes. The gender verification in sport had origin in 1948 when the British Women's Amateur Athletic Association required a doctor's letter certifying the sex of women competitors. Soon in 1966, considering that this method was poorly effective an inspection in front of a panel of three women doctors was required at the Budapest European Track and Field Championship. At the 1966 Commonwealth Games in Kingston, a manual examination of the external genitalia was carried out by a gynaecologist on all female athletes, and in 1967, at the European Cup final in Kiev, close-up visual inspection of genitalia was used to establish eligibility (Facius, 2004). Afterwards, in the Commonwealth Games in Jamaica a manual examination of the external genitalia was performed by a gynecologist (Ferris, 1992; Ferguson-Smith, 1998). Also, in Canada at the Pan American Games a visual inspection was carried out (Elsas et al., 2000). 
After the questioning of the true sex of some women athletes at the European Track and Field Championship held in Budapest, the gender verification test included a method consisting of buccal smear and x-chromatin analysis to rapidly determining the sex of participants (Hay, 1972). This method rapidly extended to other international events (Hay, 1972). Examination of cells from the buccal mucosa shows a chromatin mass, the Barr bodies, which probably represent an inactive $\mathrm{X}$ chromosome attached to the nuclear membrane in most female cells (Barr, 1972). The number of the Barr bodies is one less than the number of chromosome and they are absent in male. This method was applied due to its rapid realization which gave the possibility to check the gender of a large number of athletes in a relatively short time and because it was inexpensive. The purpose of the buccal smear was to avoid the shame of athletes to undress and the degrading inspection in front of a panel of gynaecologists (Anonymous, 1967; Genel, 2002).

While chromosomal analysis may take several days to obtain results, chromatin stains can help to determine the presence or absence of a second $X$ chromosome and fluorescent $Y$ stains can help identify the $Y$ chromosome (Moore, 1966). Some patients may exhibit asymmetrical staining suggesting genetic mosaicism (Ogilvy-Stuart \& Brain, 2004). Nevertheless, the buccal smear method is not accurate in determining the chromosomal pattern, since the absence of Barr bodies could be due not only to 46/XY normal males, but also to 45/XO (Turner's syndrome), or mosaics in which different body tissues have a different chromosomal make-up. Also, chromatin-positive persons may be 46/XX (normal female), 47/XXX (triple-X syndrome), 47/XXY (Klinefelter's syndrome), or mosaics (Anonymous, 1967; de la Chapelle, 1986; Daher et al., 1986). Since 1970s, this method has been discarded by several scientists as common diagnostic tool because technically unreliable (Simpson et al., 1993; Dickinson et al., 2002): women, who have genetic abnormalities that offer no conceivable strength advantage, are disqualified unfairly, while some men with genetic disorder would pass the sex chromatin test. A complete study of the kariotype is determined only in case of doubt because of its cost and of the prolonged time that it requires. Although a number of scientists published objection in medical journals (de la Chapelle, 1986a, 1986b, 1987, 1988) and in 1988 a meeting was promoted by the genetist de la Chapelle, the IOC did not change its policy (de la Chapelle, 1988; Elsas et al., 2000). In the same year, Maria Patiño, after two years of fights and with the help of specialists in endocrinology and genetics, obtained the reinstatement as a woman for sport and the possibility to compete in women only competitions.

The IAAF promoted symposia and work groups of scientific experts in Monte Carlo in 1990 and in London in 1992, accepting the results pointed out, so that individuals with genetic abnormalities raised as females and with no unfair physical advantages (including those with 21-steroid-hydroxylase and 5-a-steroidreductase deficiency, incomplete androgen insensitivity and chromosomal mosaicism) should be admitted to compete, as the individuals that underwent sex rearrangement surgery in prepubertal age, while postpubertal transsexual cases should be considered case by case; also they advised about the need to abandon screening of athletes through genetic testing of $Y$ chromosome (Hipkin, 1991; Simpson et al., 1993; Elsas et al., 2000).

The International Olympic Committee (IOC) did not follow the same path and decided to introduce since 1992 in Albertville a more modern scientific technique, the Polymerase Chain Reaction (PCR) analysis of the Sry gene. However, this method is able to provide information of the presence of $Y$ chromosome also in female pseudohemaphroditism so that its use seems to be limited (Fausto-Sterling, 2000; Sultan et al., 2002). Considering the protocol used at the Barcelona Olympic Games of 1992 (Serrat \& García de Herreros, 1996) and the results showing incongruity between expression of SRY and DYZ1 sequences on 
the $Y$ chromosome and the higher likelihood of finding DYZI sequences in female athletes as opposed to unselected female controls further our understanding of the technical limitations of this test (Puffer, 1996).

At the 12th Asian Games in Hiroshima in 1994 a study (Yamaoka \& Kanbe, 1995) on the human genomic DNA extracted from the hair root of female competitors was used to validate the method of the Polymerase Chain Reaction (PCR) in order to prove the absence of the sex determining region of Y-chromosome (SRY) and confirm the femininity, and detection of pseudo autosomal boundary region of Y-chromosome (PABY).

In 1994 the Norway government denied the IOC gender verification tests during the Lillehammer Olympic Games declaring the tests illegal and unethical (Elsas et al., 2000; Ljungqvist et al., 2006). Advised of the ethical and technical inappropriateness of the techniques used so far, the IOC decided in 1999 to suspend the gender verification in all sports events which sponsored, maintaining a conditional basis for later review. The International Volleyball Federation was the last institution to leave the gender verification testing in 2004 (Genel \& Ljungqvist, 2005).

Athletes with some DSD have either avoided the gender verification for the fear to view their condition publicly divulgated on the mass media or were excluded from competitions though they did not suspect irregularities in their chromosomal arrangement, as the cases of the sprinter Ewa Klobukowska and the hurdler Maria Patiño. After a hard fight with the help of scientists and experts, Maria Patiño obtained her reinstatement as woman for sport and was allowed to compete (Carlson, 2005; Martínez-Patiño, 2005). Her efforts served as first action towards the abolition of the gender verification in international competitions, but the repercussion on her personal life was devastating (Peel, 1994).

Under external pressure, the IOC adopted a policy enabling transsexual athletes to compete in the 2004 Olympic Games held in Athens (Gooren \& Bunck, 2004; Cavanagh \& Sykes, 2006) with the condition that they should have two years post surgery and continued hormone therapy (Carlson, 2005). In this sense, the policy recommended by the IOC might suggest that thought that this finally closed a difficult chapter in the path towards full integration of women in sport (Elsas et al., 2000; Simpson et al., 2000; Dickinson et al., 2002; Ljungqvist et al., 2006). Nothing is farther from the reality because the transgender policy is strictly limited to athletes who have undergone sex reassignment (it has nothing to do with DSD athletes) and the fact the womanhood of a South African athlete, Caster Semeya, winner in the 800 meter athletic specialty in the 2009 Summer World Championships held in Berlin, was questioned, when medical aspects that should have treated with totally and absolutely confidentiality about this case according to the rigor of strict medical ethics were leaked to the press. One may well ask how this conduct represents a deviation from the previous practices and if a real change has been done in the IOC policy. In fact the IOC conditioned the suspension of the sex test and gender verification to the right to inspect those female athletes suspected of gender ambiguity (Cole, 2000).

After the Caster Semenya case, the IOC organized a meeting in January 2010 in Miami where the most eminent scientists in the field were invited to address the specific problems of assigning sexual identification and propose new methods based on modern techniques. The Committee is now considering the possibility to give the responsibility of gender verification tests to specialized centers disseminated all over the world, conscious that not all countries have the same level of technology. 


\section{DISCUSSION}

The IOC policy simply says that the medical authority at a competition should have the right to conduct an investigation into an athlete's sex, if that is deemed wishful to identify the sex ambiguities of the athletes based on the assumption of a clear and absolute dimorphism in humans, so that only two sex classes are considered (male and female). As observed by Conte and Grumbach (1989) and by Blackless et al. (2000) this absolute separation does not exist. IOC often confuses sex with gender, when they are completely separate concepts: scientists define sex according to physical characteristics, while gender is a social concept and coincide with the psychological conviction that one is male or female, the so called gender identity (Fausto-Sterling, 2000; Wilson, 2000). The practice of sex testing actually makes visible both the construction of sex categories and the oppressiveness of their application by sport institutions (Wackwitz, 2003).

The life and the career of Caster Semenya, as occurred to others in her situation in the past, have been irremediably changed and nothing would be as before of the gender verification test. IOC and IAAF tried to use science to decide if some males have perpetrated a fraud to get into women's competition and if a deliberate fraud has been committed. Along the years they innovated the methods but not the aim, trying to fit different individuals into two categories when scientists and experts warned about the impossibility and the lack of ethics of their attitude.

At the beginning of the twenty-first century, with the support of ongoing medical research in the fields of diagnosis and treatment of complex sex determination in humans, it is necessary to establish parameters to determine with scientific rigor genetic issues. Hormonal, biological and psychological factors must be taken into account where uncertain or ambiguous cases in female athletes occur and must be considered eligible to participate in sporting events. These disorders of sexual differentiation in sports have existed, exist and will always exist, and it is high time to determine with medical facts what to do in these situations.

\section{Psychological and social repercussions of gender verification}

Many factors are involved in sexual identity beyond chromosomal makeup such as an early imprinting of the brain based on hormonal exposure (Diamond, 2002), a complex interaction between prenatal and postnatal endocrine factors, genetic influences, and postnatal environmental and psychological experiences. Science has revealed many of the genetic and hormonal pathways responsible for inter-sex disorders (Forest, 2001), but the psychological aspects of the physical statement of gender assignment could perhaps be even more critical in the final picture of social adjustment, and are still poorly understood (Bomalaski, 2005).

Gender verification testing of women in international competitions could be considered as an abusive, unethical and discriminative practice which was carried out by high level sports institutions for decades. The need to apply a gender verification test was considered in response to the masculine aspect of some Soviet champions during the Cold War. The nationalism feelings of Americans could not afford the hegemony of athletes from Soviet Union in many sports, so that they hypothesized the unfair participation of men in women only competitions or the belief that hormone therapy was applied by Soviet trainers to change boys in girls or virilizing female athletes (Wiederkehr, 2009). The gender verification seemed the best solution to avoid dishonest participations in female only competitions. Only two men have been confirmed to have competed in female events pretending to be women in the 1940s and 1960s. 
When they have to submit to routine gynecological examination, most women suffer episodes of shame and decency due to the uncomfortable feelings of being observed by a stranger. If we also consider that in the past, and still today in less developed countries, women did not undergo to gynecological examinations unless they did not have a serious problem, we could imagine the feelings of thousands of women that passed through the genital examination of the gender verification process until 1967. It is not surprising that some women refused to subjugate to these unpleasant practices, as occurred when this system was applied for the first time. Six women did not present to the gender verification in that occasion, including Tamara and Irina Press, the two Soviet sisters who were the greatest athletes of that époque (Carlson, 2005). Although supposing that the absence of these athletes at the gender verification was due only on the basis of emotional causes or an injury could appear too simple and ingenuous, no real proof of irregularities in their genitals or chromosome arrangement has been provided. We can only hypothesize that they probably were affected by some kind of disorder of sex development, showing some abnormalities in their external genitalia. In front of the possibility of being object of examination, of discrimination and viewing publicly divulgated their condition, these and other women preferred to withdraw before to submit to gender verification tests (Elsas et al., 2000). On the other hand the two champions declared that their absence from competitions was not due to the examination of the gender verification itself (Wiederkehr, 2009), although their absence enhanced the gossip that they would probably fail the test. Also at that time there was a great confusion on what was the range of the gender verification, which in many cases was confused and correlated with the drug testing (also introduced in 1967). The use of anabolic steroids to enhance muscular development and strength caused alteration of the female phenotype, such as deepening voice and facial hair growth, so that the masculine aspect of the athletes was considered checkable with a gender test.

The introduction of the chromatin test, which many problems of shame and protests should solve, was the cause of injustice and discrimination along the woman history of sport. The knowledge about people with disorders of sex development was limited and not available to everyone, and less to people who were unaware or unable to understand genetic issues. Many women were asked to graciously withdraw from sport life or to pretend a serious injury when obtaining a positive result from the gender verification test by buccal smear, probably a number much higher than we suspect (Elsas et al., 2000; Martínez-Patiño, 2005; Fox, 1993; Genel, 2002). Without any doubt the gender verification system ended with their sports careers, but the devastating repercussion on the personal and social lives of those individuals whose stories were leaked to the mass media (Wiederkehr, 2009) is another matter: suddenly they were not women any more, nor they were considered men. The social rejection and the affliction in most cases affected also the family and friends of subjects with DSD, and unfair attitude remains after the death of the interested person, as was for the athlete Stella Walsh. She was reared as girl at birth, was raised as female, got married, and competed at high level, but after her death and the public divulgation of her mosaic chromosomal pattern and abnormality of genitals she is still referred as "he/she" in many records books (Carlson, 2005).

The same psychological problems experimented in sport by individuals with clear genital abnormalities were even harder to board when the abnormalities were unsuspected. Most of male pseudohermaphrodites are reared as female at birth, raised as female and in many cases unaware of their different condition. Ewa Klobukowska and Maria Patiño, for example, knew their disorder of sex development by the gender verification test and never before they have considered themselves something different than normal women. After her obligated retirement from competitions and the retirement of all her medals and records, Ewe Klobukowska felt a deep depression and decided to undergo surgery and to follow a hormone therapy to reassess her sex as woman. She broke off all the contacts with the sports world (Langlais, 1988; Facius, 2010; Carlson, 2005). Maria Patiño was advised to pretend an injury and quietly withdraw, when her gender 
test gave positive. She considered herself nothing different of a female so refused to leave competition and was disqualified in 1985. Her willpower allowed her not to give up with sport, to investigate the cause of her difference and to look for help in experts of both medical and sport fields to be restated as woman for sport. During her hard struggle she had suffered the mock of people who called her witch, the continuous rumours, the impotence to see her parents and family suffering for the situation, the lose of the closest people such as her boyfriend and her friends. She had to submit to public shame and to internal questioning about herself, convinced in all moment of her honesty and her womanhood (Peel, 1994; Carlson, 2005; Cavanagh \& Sykes, 2006; Martínez-Patiño, 2005). Only 50\% of undervirilized 46,XY subjects obtain a definitive diagnosis (Houk et al., 2006) and she probably would never be aware of the atypical chromosome pattern if she did not practice high level sport. Caster Semenya declared her womanhood in front of sport institutions and after the failure of the gender test she affirmed to be a female as she was always reared. When her condition was divulgated to the press and other media, a part to have to deal with an internal conflict and challenge, she experimented the beginning of a discriminatory attitude from the society and the insistent interest of people to all what concerns her condition.

Sexual boundaries are not so defined and separated in two classes (male and female) as the society and sports institutions generally intend, being present a wide range of intermediate sexual conditions which have to be taken into account. The IOC decision at the Miami meeting to create centers where the athletes with ambiguous genitalia or atypical chromosome arrangement will be treated with the privacy that the instance deserves is a step towards the reach of good practices in gender verification. The multidisciplinary approach of these centers should include a protocol sufficiently flexible and diversified to consider the different facets of such kind of situations including a psychological support for the athletes and if opportune for the family. To minimize the psychological distress, the subjectfamily should be informed exactly and clearly about the kind of assays and the consequences of the possible results.

We agree that a control on the medical conditions should be conducted for the health of the athletes, indistinctly for men and women, and we pretend that the gender verification change its discriminative perspective against DSD athletes at the same time that a more ethical and sensitive attitude is adopted by sports institution in considering each situation. People reared as female at birth and grown up as female, should not be consider differently by sports institutions though their chromosomal arrangement is different from the expected. An endogenous advantage given to the athletes by their DSD condition over competitors is not easily quantifiable and should not be quantified as should not in other kinds of genetic mutations that do not affect sex and gender assignment but that give a phenotype that favors the excellence in a particular sport activity. On the other hand, sportsmen and sportswomen should be informed on their health problems with the assistance of psychologists and well trained physicians.

The time of fraudulent intents of some men to participate in women competitions is very far (only one men was confirmed to participate in women competitions and did not have any advantage over other participants since he classified fourth), and nowadays gender verification is out of meaning. It is important that the sports institution respect the psychosexual development of DSD athletes, giving them the opportunity to compete as men or women according to their gender assignment.

Above all, the medical decision should be the unquestionable parameter for determining gender sports eligibility. These cases are no longer an issue to be analyzed from the sports point of view, but from a medical one and should under no circumstances be exposed publicly as happened to Caster Semeya, where there was no discretion or consideration to protect the athlete from the difficult and tense situation that ensued. 
Under the Medical Commission of International Olympic Committee and with the experience of many cases throughout decades of women participating in the Olympics, the controversy should end, based on taking the recommendations and advice of scientists in all medical fields of study, providing sports organizations and their leaders something they hope to achieve as well, the eradication of such unfortunate situations. These recommendations supported by the research of medical, ethical and sports experts will determine a substantial and specific way what can be done in such cases in the future.

And above all, these decisions cannot be questioned by external and inexperienced individuals who only induce human trauma of great pain and frustration to the helplessness athletes and their families. Their whole future as human beings is full of doubt just for having chosen to do high-level sport, never having the intention to deceive anyone. Nobody can compare these present day situations to those fraudulent attempts in the decades of the $40 \mathrm{~s}$, $50 \mathrm{~s}$ and $60 \mathrm{~s}$ when some men intended to compete as women, specifically in the 1972 Munich Olympics it was alleged that one of the Asian women's volleyball teams included a man. These circumstances are medically and psychologically different and in the 21 st century are unthinkable.

The imperfections of genetic testing which draw erroneous conclusions of their condition must not be used against women athletes nor allowed to be known by sports organizations in the media that slander the athlete. If this situation is not clarified and the recommendations of the experts are not taken into account, in the future women with an ambiguous condition will always be questioned, and they will feel helpless lacking the solid arguments needed to fight this discriminative attitude. Most importantly, at all times they must have the scientific, medical and human support to overcome the new reality they are facing. It is essential that experts take into account the need to include psychological support to affected women in order to help them to reintegrate into society accepting their particular condition.

\section{CONCLUSIONS}

For decades, women who belonged to a selective group of high level competition sports have undergone tests to ascertain whether they could be considered as "women" in order to participate in their respective sport categories.

We have gone from the humiliating visual checks that were established in the beginning of times to later medical controls that reinstated this humiliation on the basis of science lacking a thorough basis in order to decide whether they should participate in sports or not, considering them genetically faulty side by side with others that were denominated "genetically correct," according to the existing regulation.

It was Prof. de la Chapelle, a specialist in genetics, who established a turning point and who showed the ruling committees of sports the mistakes and injustice that they were falling into by limiting the definition of gender in sports to a simple genetic control. Much thought, controversy and struggle have been devoted to suppress the systematic controls that questioned many women who found in sports a way to project their talent and their abilities.

These women, unfairly treated and hardly supported by the institutions that were supposed to defend them in sports, found in one of the leaders of the sports world, Prof. Arné Ljungqvist, a broader vision in order to elicit a solution and an adequate management of their situation. This way, their particular cases could be treated and analyzed individually by experts, out of the scope of the media, and within specialized centres 
with the adequate advances of medicine in the field of sports. This "new age" in which a more humane, fair and confidential treatment is guaranteed would be the best way out to banish those humiliating situations of the past and recent past which made sport women and their families dramatically drag their personal histories as a heavy burden for the rest of their lives.

\section{ACKNOWLEDGEMENTS}

We sincerely acknowledge the comments and the text revision of Prof. Arne Ljungqvist, Chairman IOC Medical Commission and Prof. Dr. Myron Genel (Yale University School of Medicine).

\section{REFERENCES}

1. ANONYMOUS. Sex of athletes. British Medical Journal. 1967; 1:185. doi:10.1136/bmj.1.5534.185 [Back to text]

2. BARR ML. Some notes on the discovery of the sex chromatin and its clinical application. Am. J. Obstet. Gynecol. 1972; 112(2): 293-6. [Abstract] [Back to text]

3. BERKOVITZ GD, SEEHERUNVONG T. Abnormalities of gonadal differentiation. Baillieres Clin Endocrinol Metab. 1998; 12(1):133-42. doi:10.1016/S0950-351X(98)80512-0 [Back to text]

4. BLACKLESS M, CHARUVASTRA A, DERRYCK A, FAUSTO-STERLING A, LAUZANNE K, LEE E. How sexually dimorphic are we? Review and synthesis. American Journal of Human Biology. 2000; 12(2)151-166. doi:10.1002/(SICl)1520-6300(200003/04) [Back to text]

5. BOMALASKI MD. A practical approach to intersex. Urol. Nurs. 2005; 25(1):11-18, 23-24. [Abstract] [Back to text]

6. CARLSON A. Essay suspect sex. The Lancet. 2005; 366:S39-S40. doi:10.1016/S01406736(05)67842-7 [Back to text]

7. CAVANAGH SL, SYKES H. Transsexual bodies at the Olympics: the International Olympic Committee's policy on transsexual athletes at the 2004 Athens summer Games. Body \& Society. 2006; 12(3):75-102. doi:10.1177/1357034X06067157 [Back to text]

8. COLE CL. Testing for sex or drugs? Journal of Sport and Social Issues. 2000; 24(4):331-333. doi:10.1177/0193723500244001 [Back to text]

9. CONTE FA, GRUMBACH MM. Pathogenesis, classification, diagnosis and treatment of anomalies of sex. In: $L$ de Groot (Ed.). Endocrinology. New York: Suanders; 1989. Pp. 1810-1847. [Back to text]

10. DAHER V, BE C, YOULTON R. Cromatina de Barr: analisis de su valor actual. Rev. Chil. Pediatr. 1986; 57(6):506-509. doi:10.4067/S0370-41061986000600006 [Back to text]

11. DE LA CHAPELLE A, GENEL M, SCHWINGER E. Gender verification of female athletes. The Lancet. 1987; 330(8570):1265. [Back to text]

12. DE LA CHAPELLE A. Stop the sex chromatin test in sports medicine. A bad selective method causing tragedy. Lakartidningen. 1988; 85(42):3449. [Back to text]

13. DE LA CHAPELLE A. The etiology of maleness of XX men. Hum. Genet. 1981; 58:105-116. doi:10.1007/BF00284157 [Back to text]

14. DE LA CHAPELLE A. The use and misuse of sex chromatin screening for "gender verification" of female athletes. JAMA. 1986b; 256(14):1920-1923. [Abstract] [Back to text]

15. DE LA CHAPELLE A. Why sex chromatin should be abandoned as a screening method for 'gender verification' of female athletes. New Studies in Athletics (London), IAAF Medical congress; 1986a. Pp. 49-53. [Back to text] 
16. DIAMOND DA. Sexual differentiation: normal and abnormal. In: PC Walsh, AB Retik, ED Vaughn, \& AJ Wein (Eds.). Campbell's urology (8th ed.). Philadelphia: W.B. Saunders Company; 2002. Pp. 2406-2407. [Back to text]

17. DIAMOND M. Sex, gender, and identity over the years: a changing perspective. Child Adolescent Psychiatric Clinics of North America. 2004; 13(3):591-607. doi:10.1016/j.chc.2004.02.008 [Back to text]

18. DICKINSON BD, GENEL M, ROBINOWITS CB, TURNER PL, WOODS GL. Gender verification of female Olympic athletes. Med. Sci. Sports Exerc. 2002; 34(10):1539-1542. [Abstract] [Back to text]

19. ELSAS LJ, LJUNQVIST A, FERGUSON-SMITH MA, SIMPSON JL, GENEL M, CARLSON A, FERRIS E, DE LA CHAPELLE A, EHRHARDT AA. Gender verification of female athletes. Genet. Med. 2000; 2(4):249-254. [Abstract] [Back to text]

20. FACIUS GM. The major medical blunder of the $20^{\text {th }}$ century. 2004. Consulted on 05/02/2010. http://www.123hjemmeside.dk/gender_testing. [Back to text]

21. FACIUS GM. The major medical blunder of the 20th century. 2010 Consulted on 22/01/2010. http://www.intersexualite.org//OC.html. [Back to text]

22. FAUSTO-STERLING A. Sexing the body: gender politics and the construction of sexuality. Perseus. New York; 2000. [Back to text]

23. FECHNER PY. The role of SRY in mammalian sex determination. Acta Paediatr Jpn. 1996; 38(4):380-9. [Abstract] [Back to text]

24. FERGUSON-SMITH MA, FERRIS EA. Gender verification in sport: the need for change? Br. J. Sports Med. 1991; 25:17-20. doi:10.1136/bjsm.25.1.17 [Back to text]

25. FERGUSON-SMITH MA. Gender verification and the place of XY females in sport. In: W Harris, $C$ Williams, W Stanish, L Micheli. (Eds.). Oxford Textbook of Sports Medicine. Oxford, England: Oxford University Press; 1998. Pp. 355-365. [Back to text]

26. FERRIS EA. Gender verification testing in sport. Br. Med. Bull. 1992; 48(3):683-97. [Abstract] [Back to text]

27. FORD CE, JONES KW, POLANI PE, DE ALMEIDA JC, BRIGGS JH. A sex-chromosome anomaly in a case of gonadal dysgenesis (Turner's syndrome). The Lancet. 1959; (7075):711-3. [Abstract] [Back to text]

28. FOREST MG. Ambiguous genitalia/intersex: Endocrine aspects. In: JP Gearhart, RC Rink, \& PDE. Mouriquand (Eds.). Pediatric urology. Philadelphia: W.B. Saunders Company; 2001. Pp. 623-658. [Back to text]

29. FOX JS. Gender verification - What purpose? What price? Br. J. Sports Med. 1993; 27:148-149. doi:10.1136/bjsm.27.3.148 [Back to text]

30. FRACCARO M, KAIJSER K, LINDSTEN J. Chromosome complement in gonadal dysgenesis (Turner's syndrome). The Lancet. 1959; 273(7078):886. [Back to text]

31. FRANCAVILLA S, CORDESCHI G, PROPERZI G, CONCORDIA N, CAPPA F, POZZI V. Ultrastructure of fetal human gonad before sexual differentiation and during early testicular and ovarian development. J. Submicrosc. Cytol. Pathol. 1990; 22(3):389-400. [Abstract] [Back to text]

32. GENEL M, LJUNGQVIST A. Essay Gender verification of female athlete. The Lancet. 2005; 366:S41. doi:10.1016/S0140-6736(05)67843-9 [Back to text]

33. GENEL M. Gender verification no more? Madscape Women's Health. 2002; 5(3):2000. [Abstract] [Back to text]

34. GOOREN LJG, BUNCK MCM. Transsexuals and competitive sports. European Journal of Endocrinology. 2004; 151:425-429. doi:10.1530/eje.0.1510425 [Back to text]

35. GRUMBACH MM, CONTE FA. Disorders of sexual differentiation. In: JD Wilson (Ed.). Williams Textbook of Endocrinology, 9th Ed. Philadelphia: Saunders; 1998. Pp. 1303-1425. [Back to text] 
36. HAY E. Sex determination in putative female athletes. JAMA. 1972; 4:39-41. [Abstract] [Back to text]

37. HIPKIN LJ. Gender verification in sport. Br J Sports Med. 1991; 25(3):171. [Full Text] [Back to text]

38. HIPKIN LJ. The XY female in sport: the controversy continues. Br J Sports Med. 1993; 27(3):150156. [Full Text] [Back to text]

39. HOUK CP, HUGHES IA, AHMED SF, LEE PA, WIICCP. Summary of consensus statement on intersex disorders and their management. Pediatrics. 2006; 118(2):753-757. doi:10.1542/peds.2006-0737 [Back to text]

40. HUGHES IA. Disorders of sex development: a new definition and classification. Best Pract Res Clin Endocrinol Metab. 2008; 22(1):119-134. doi:10.1016/j.beem.2007.11.001 [Back to text]

41. HUGHES IA. Intersex. British Journal of Urologic International. 2002; 90(8):769-776. doi:10.1046/j.1464-410X.2002.02920.x [Back to text]

42. JOHANNSEN TH, RIPA CPL, MORTENSEN EL, MAIN KM. Quality of life in 70 women with disorders of sex development. European Journal of Endocrinology. 2006; 155:877-885. doi:10.1530/eje.1.02294 [Back to text]

43. KIM K, KWON Y, JOUNG JY, KIM KS, AYALA AG, RO JY. True hermaphroditism and mixed gonadal dysgenesis in young children: a clinicopathologic study of 10 cases. Modern Pathology. 2002; 15(10):1013-1019. doi:10.1097/01.MP.0000027623.23885.0D [Back to text]

44. KRIMSKY S. An epistemological inquiry into the endocrine disruptor thesis. Ann N Y Acad Sci. 2001; 948:130-42. doi:10.1111/j.1749-6632.2001.tb03994.x [Back to text]

45. LANGLAIS D. The road not taken: the sex secret that really didn't matter. Running Times; 1988. Pp. 21-22. [Back to text]

46. LEE PA, HOUK CP, AHMED SF, HUGHES I.A. Consensus Statement on management of intersex disorders. Pediatrics. 2006; 118:e488-e500. doi:10.1542/peds.2006-0738 [Back to text]

47. LISKER R, RUZ L, MUTCHINICK 0. 45,X/47,XYY mosaicism in a patient with Turner's syndrome. Hum Genet. 1978; 41(2):231-3. doi:10.1007/BF00273106 [Back to text]

48. LJUNGQVIST A. MARTÍNEZ-PATIÑO MA, MARTÍNEZ-VIDAL A, ZAGALAZ L, DÍAZ P, MATEOS C. The history and current policies on gender testing in elite athletes. ISMJ, 2006; 7(3):225-230. [Abstract] [Back to text]

49. MARTÍNEZ-PATIÑO MJ. Personal account a woman tried and tested. Lancet. 2005; 366:S38. doi:10.1016/S0140-6736(05)67841-5 [Back to text]

50. MOORE KL. The sex chromatin. Philadelphia and London: W. B. Saunders; 1966. [Back to text]

51. OGILVY-STUART AL, BRAIN CE. Early assessment of ambiguous genitalia. Arch Dis Child. 2004; 89(5):401-407. doi:10.1136/adc.2002.011312 [Back to text]

52. PAJKRT E, CHITTY LS. Prenatal gender determination and the diagnosis of genital anomalies. British Journal of Urology International. 2004; 93(3):12-19. doi:10.1111/j.1464-410X.2004.04704.X [Back to text]

53. PEEL R. Maria's Story. "Eve's Rib-Searching for the Biological Roots of Sex Differences". Crown Publishers: New York; 1994. [Back to text]

54. PERRAULT M, KLOTZ B, HOUSSET E. Deux cas de syndrome de Turner avec surdi-mutite dans une meme fratrie. Bull Mem Soc Med Hop. 1951; 16:79-84. [Back to text]

55. PUFFER JC. Gender verification: a concept whose time has come and passed? Br J Sports Med. 1996; 30:278. doi:10.1136/bjsm.30.4.278 [Back to text]

56. RABINOVICI R, JAFFE RB. Development and regulation of growth and differentiated function in human and subhuman primate fetal gonads. Endocr Rev. 1990; 16:532-557. doi:10.1210/edrv-114-532 [Back to text] 
57. REY R, JOSSO N. Sexual Differentiation. In: JD Baxter, S Melmed, MI New (Eds.). Genetics in Endocrinology. Philadelphia: Lippincott Williams \& Wilkins Publishers. 2002. [Back to text]

58. RICHTER-APPELT H. Intersexuality. Disorders of sex development. Bundesgesundheitsblatt Gesundheitsforschung Gesundheitsschutz. 2007; 50(1):52-61. [Abstract] [Back to text]

59. SERRAT A, GARCÍA DE HERREROS A. Gender verification in sports by PCR amplification of SRY and DYZ1 Y chromosome specific sequences: presence of DYZ1 repeat in female athletes. Br J Sports Med. 1996; 30(4):310-312. doi:10.1136/bjsm.30.4.310 [Back to text]

60. SIMPSON JL, LJUNGQVIST A, DE LA CHAPELLE A, FERGUSON-SMITH MA, GENEL M, CARLSON AS, EHRHARDT AA., FERRIS E. Gender verification in competitive sports. Sports Med. 1993; 16(5):305-315. [Abstract] [Back to text]

61. SIMPSON JL, LJUNGQVIST A, FERGUSON-SMITH MA, DE LA CHAPELLE A, ELSAS LJ, EHRHARDT AA, GENEL M, FERRIS EA, CARLSON A. Gender verification in the Olympics. JAMA. 2000; 284(12):1568-9. [Abstract] [Back to text]

62. SYBERT VP, MCCAULEY E. Turner's syndrome. N Engl J Med. 2004; 351(12):1227-1238. [Full Text] [Back to text]

63. THYEN U, HAMPEL E, HIORT O. Disorders of sex development. Bundesgesundheitsblatt Gesundheitsforschung Gesundheitsschutz. 2007; 50(12):1569-1577. [Abstract] [Back to text]

64. WACKWITZ LA. Verifying the myth: Olympic sex testing and the category "woman". Women's Studies International Forum. 2003; 26(6):553-560. doi:10.1016/j.wsif.2003.09.009 [Back to text]

65. WARNE GL, RAZA J. Disorders of sex development (DSDs), their presentation and management in different cultures. Rev Endocr Metab Disord. 2008; 9:227-236. doi:10.1007/s11154-008-9084-2 [Back to text]

66. WIEDERKEHR S. 'We shall never know the exact number of men who have competed in the Olympics posing as women': sport, gender verification and the cold war. The International Journal of the History of Sport. 2009; 26(4):556-572. doi:10.1080/09523360802658218 [Back to text]

67. WILSON DR, SIMPSON JL, LJUNGQVIST A, FERGUSON-SMITH MA, DE LA CHAPELLE A, ELSAS LJ, EHRHARDT AA, GENEL M, FERRIS EA, CARLSON A. Gender vs Sex. JAMA, 2000; 284(23):Letters. [Abstract] [Back to text]

68. YAMAOKA K, KANBE M. Gene diagnostics of gender verification test in competitive sports. Rinsho Byori. 1995; 43(8):799-804. [Abstract] [Back to text]

69. ZUFFARDI O, GARGANTINI L, LAMBIASE S, LO CURTO F, MARASCHIO P, FORD CE. Presumptive mosaic origin of an XX/XY female with ambiguous genitalia. J Med Genet. 1987; 24(3):177-80. doi:10.1136/jmg.24.3.177 [Back to text] 